\title{
A Study on Resting Cysts of an Oxytrichid Soil Ciliate, Rigidohymena quadrinucleata (Dragesco and Njine, 1971) Berger, 2011 (Ciliophora, Hypotrichia), Including Notes on its Encystation and Excystation Process
}

\author{
Simona BENČAŤOVÁ and Eva TIRJAKOVÁ \\ Department of Zoology, Faculty of Natural Sciences, Comenius University in Bratislava, Slovak Republic
}

\begin{abstract}
This is the first detailed study on the morphology of the resting cysts of an oxytrichid ciliate, Rigidohymena quadrinucleata. Resting cysts were investigated using light microscopy, SEM and TEM. The cyst wall is composed of four distinct layers (from inside to outside), namely the metacyst, the endocyst, the mesocyst and the ectocyst with spine-like protuberances. The cysts of $R$. quadrinucleata belong to the kinetosome-resorbing (KR) type, which is typical for oxytrichids. The processes of encystation and excystation were observed only in the light microscopy. During the encystation process, the trophic cell changes in shape and volume due to dehydration, four macronuclear nodules fuse into a compact mass, the ciliature is resorbed and cyst wall is formed. The most significant feature is surface ornamentation and yellowish color of resting cysts. We also focuse for the first time on excystation process of $R$. quadrinucleata. We identified two excystation modes: (i) standard and (ii) rare mode. The beginning of both excystation is characterised by the formation of excystation vacuole which helps the excysting cell to break the cyst wall. The specimen regenerates within a thin, flexible membrane. During the standard mode, the cell leaves the resting cyst in the membrane that is resorbed in the environment. During the rare mode, the excystation vacuole and the pressure of the regenerating cell break the transparent membrane that remains in the resting cyst. The results suggest that not only ciliate resting cysts, but also the excystation process is much more variable than what literature data indicate.
\end{abstract}

Key words: Cyst wall, morphology, Oxytrichidae, resting cyst, ultrastructure

\section{INTRODUCTION}

Rigidohymena quadrinucleata (Dragesco and Njine, 1971) Berger, 2011 is a large soil ciliate, preferring terestrial and semiterestrial habitats (Berger 1999, 2011; Wang et al. 2017). Originally, this species was discovered in a leaf-littered pond near Yaounde,

Address for correspondence: Simona Benčat'ová, Department of Zoology, Faculty of Natural Sciences, Comenius University, Mlynská dolina B-1, SK-842 15 Bratislava, Slovak Republic; E-mail: bencatova.simona@gmail.com
Cameroon and described as Steinia quadrinucleata by Dragesco and Njine in 1971. In addition, the species was found by Foissner (1984) in the upper soil layer of a conventionally farmed field in Salzburg, in Austria and later was also found in soils from Namibia, Antarctica, Brazil and China (Foissner 1997, Berger 1999, Wang et al. 2017). Somewhat later, Foissner (1989) created the genus Cyrtohymena and the species Steinia quadrinucleata was transferred to a taxon as Cyrtohymena quadrinucleata. The characterisation of this genus is according to Berger and Foissner (1997). In 2011, Berger established the new oxytrichid genus 
Rigidohymena, that is characterised by a rigid, inflexible body, the absence of cortical granules, oral aparatus Cyrtohymena-like, length of adoral zone about $40 \%$ of the cell body, usually 18 frontal-ventral-transverse cirri, caudal cirri present and dorsal ciliature in an $O x y$ tricha-like pattern. Thus, the several species including C. quadrinucleata were assigned to a new taxon, Rigidohymena (Berger 2011). Presently, the genus Rigidohymena contains four species: type species $R$. tetracirrata (Gellért, 1942) Berger, 2011; R. candens (Kahl, 1932) Berger, 2011; $R$. inquieta (Stokes, 1887) Berger (2011) and R. quadrinucleata (Dragesco and Njine, 1971) Berger, 2011.

Previous records of its occurrence indicate that $R$. quadrinucleata is apparently a common species. Because of its common occurence and because it grows well in laboratory conditions, its interphase morfology, morphogenesis and molecular phylogeny were investigated, e.g. by Berger (1999) and Wang et al. (2017). On the other hand, detailed information on the resting cysts morphology, as well as processes during encystation and excystation are still lacking. Some information on the resting cysts of other species of genus Rigidohymena are very poor. Basic characteristics were summarised for the type species Rigidohymena tetracirrata (Gellért, 1942) Berger, 2011 and species R. candens (Kahl, 1932) Berger, 2011 in Berger (1999). Furthermore, a brief description of resting cysts is provided, e.g. for the species Cyrtohymena citrina (Berger and Foissner, 1987) Foissner, 1989 in Singh and Kamra (2015) and Australocirrus australis (Foissner, 1995) Kumar and Foissner, 2015 [synonym Cyrtohymena (Cyrtohymenides) australis] in Kumar and Foissner (2015). The results of the presented study provide new interesting information on the encystation and excystation of Rigidohymena quadrinucleata and the ultrastructure of resting cysts were also studied and discussed.

\section{MATERIALS AND METHODS}

\section{Material colection and cultivation, induction of en- cystation and excystation}

Rigidohymena quadrinucleata (Dragesco and Njine, 1971) Berger, 2011 was isolated from a moss sample taken from a tree in a cemetery from the locality Jesenské, Central Slovakia $\left(48^{\circ} 18^{\prime} 7.4641471^{\prime \prime} \mathrm{N}, 20^{\circ} 4^{\prime} 9.4668961^{\prime \prime} \mathrm{E}\right)$ on November 14, 2014. The moss sample was collected from an area about $10 \mathrm{~cm} \times 10 \mathrm{~cm}$ and transported to the laboratory and subsequently used to ob- tain a raw culture in a Petri dish with a diameter of 70 and $90 \mathrm{~mm}$ (Vd'ačný and Foissner 2012). First, the specimens of R. quadrinucleata were excysted 2-3 days after hydrating the sample with tap water at room temperature. The highest abundance of specimes was on the fifth day after starting of cultivation. Later, later cells were transffered to watch glasses with a diameter of 48 and $68 \mathrm{~mm}$ and cultivated with tap water (initial volume 3-5 ml) with the addition of wheat grains or lettuce medium. Colpoda steinii Maupas, 1883 in culture served as the main source of food. The culture of R. quadrinucleata was allowed to dehydrate and re-hydrate regularly.

Factors that induce encystation are desiccation and a lack of food in the culture. We left the cultures of $R$. quadrinucleata in the watch glasses to gradually dehydrate. In about 3-4 days, dessication gradually occured and the cells began to encyst. On the contrary, we re-hydrated and revived the resting cysts with tap water and stimulated them to excyst. The 3-day-dry cultures in the watch glasses started to excyst rather quickly, about 1-2 hours after saturation with tap water. The 5-week-dry cultures started to excyst a little slower, about 2-3 hours and the 3-month-dry cultures excysted about 3-4 days after saturation. After 6-months of dehydration, the resting cysts lost the capability to excyst.

\section{Light microscopic}

Trophic cells, encystation, excystation and resting cysts were observed using the optical microscope Leica DM 1000 at low $(100-400 \times)$ and high (1000×; with immersion) magnifications. The nuclear apparatus and ciliature of trophic cells were investigated using the protargol impregnation method according to Foissner (2014). In vivo measurements were conducted at magnifications of 100-1000×. All images were captured using a Leica EC3 camera. Schemes and drawings were graphically processed in program CorelDraw X6 and X7.

\section{Electron microscopic}

Resting cysts of $R$. quadrinucleata were studied by using scanning (SEM) and transmission (TEM) electron microscopy. Preparation for scanning electron microscopy follows the protocol described by Foissner (2014). For transmission electron microscopy, resting cysts were prefixed with $2 \mathrm{ml} \mathrm{2,5 \%}$ glutaraldehyd in $0,1 \mathrm{M}$ phosphate buffer at $4{ }^{\circ} \mathrm{C}$ for 4 hours. Subsequently, the cells were washed several times with $0,1 \mathrm{M}$ phosphate buffer and fixed in $2 \mathrm{ml}$ $4 \% \mathrm{OsO}_{4}$ for 2 hours. The postfixed cells were washed again and then dehydrated through a graded series of acetones (50-70-8090-95-100\%) and transsfered to propylene oxide. Then, the cysts were mounted into epoxy blocks (SPURR) which were cut with a diamond knife (Diatome, USA) on ultramicrotome Ultratome Nova (LKB Broma). Ultrathin sections were stained with uranyl acetate followed by lead citrate (U/L staining) and observed with a transmission electron microscope JEM 2000FX at an accelerating voltage of $80 \mathrm{kV}$. The images were digitalized and improved electronically.

\section{Identification and terminology}

Identification of the species of $R$. quadrinucleata was based on Berger (1999) and Berger (2011). Terminology of interphase morphology follows Berger (1999). Resting cyst morphology is based on the works of Foissner (2005) and Foissner et al. (2007). 


\section{RESULTS}

\section{General description of morphology of cultivated trophic cells (Fig. 1A)}

Body size is usually $130-150 \mu \mathrm{m} \times 55-60 \mu \mathrm{m}$ in vivo, on average about $110 \times 50 \mu \mathrm{m}$ after protargol impregnation. Body shape ovate to long elliptical, anterior and posterior end broadly rounded; usually $2: 1$ dorsoventrally flattened. Four macronuclear nodules, left of cell midline, about $15-20 \mu \mathrm{m} \times 10-12 \mu \mathrm{m}$ in size in vivo and about $10-15 \mu \mathrm{m} \times 7.5-10 \mu \mathrm{m}$ after protargol impregnation. Usually $2-4$ spherical micronuclei; about $2-3 \mu \mathrm{m}$ in diameter after protargol impregnation; attached to macronuclear nodules at variable positions. A single contractile vacuole, left of cell midline. Cortex rigid (inflexible); cortical granules lacking. Cytoplasm courless, with cytoplasmatic crystals and more conspicuous food vacuoles in well-fed specimens.

Cirral pattern of usual variability as described in Berger (1999). Six fronto-ventral-transverse rows corresponding to cirri anlagen I-VI of typical oxytrichids (see Berger 1999 and Wang et al. 2017). Adoral zone of membranelles occupies about $40-45 \%$ of body lengtht; composed of 35 membranelles on average. Undulating membranes in typical Cyrtohymena pattern, paroral membrane curved to form a semicircle and optically intersect the endoral membrane (Berger 1999, Berger 2011, Chen et al. 2013, Wang et al. 2017).

\section{Encystation}

We studied only live observations of $R$. quadrinucleata encystation, the description is of a preliminary nature. The first morphological changes were observed 3-4 days after the beginning of desiccation of the watch glass cultures. We recognised five basic stages of the encystation process.

Stage 1. During the initial stage of encystment, the trophic cell slowed down the speed of movement. About 1-1.5 hours after the beginning of encystation, the body length shortened by an average of about 30-40 $\mu \mathrm{m}$, causing a broadly ovate cell shape. The cytoplasm became denser and darker in color, due to the water loss and overall reduction in cell content. The contractile vacuole of specimens in early stage of encystment was slower in activity, but still working and recognisable.

Stage 2. In the next stage, which took 1-2 hours, the cell length further deacresed by about other 20-30 $\mu \mathrm{m}$. A comprehensive disintegration process began in the ciliature resorption, i.e. undulating membranes, adoral zone of membranes and cirral rows were gradually resorbed.

Stage 3. Later, about 2.5 hour after the beginning of encystation, significant changes in the nuclear apparatus occured. Four macronuclear nodules began to fuse. First, the binodulate stage formed. The shape of the cell body were gradually changing into a sphere.

Stage 4. During this stage, which took 2.5-4.5 hours, the binodulate macronuclear completely started to merge into a single mass. The cell body became totally globular and the ciliature of trophic cell disappeared completely. This stage represented a young cyst. Contractile vacuole was still recognisable, but disappeared after a complete encystation and were never present in the mature cysts.

Stage 5. The last stage was represented by a mature cyst. Macronuclear mass was globular, localised in the centre of the encysting cell. The cyst wall with spinelike protuberances were finally developed.

\section{Resting cysts}

General description. The resting cysts of $R$. quadrinucleata were attached to the bottom of the culture dish or adhered to the floating debris in the culture. Attachment occured by the spine-like protuberances on the cyst surface. The cysts were yellowish, globular, in diameter about $42.5-60 \mu \mathrm{m}$ in vivo. Shortly after the encystation, the young cysts still had typical structures of trophic cells, e.g. contractile vacuole, but disapearred after a complete encystation. Morphology of the cyst wall changed during the first two days after encystation (Figs 1C, D). The cyst wall of the young cyst was smooth (Figs 2A, B), without any conspicuous structures. The cyst wall of mature cyst (after 1-2 days) had specific surface ornamentation - spine-like protuberances (Figs 2C, D, G, H, I). The cyst size did not change in time (Figs 1C, D), the changes were typical only for morphology of the cyst wall. The yellow color was also typical for all stages of resting cysts.

Cyst wall. In a light microscope, the cyst wall was composed of three distinct layers (ectocyst, mesocyst and endocyst), while four layers were recognisable in the transmission electron microscope (ectocyst, mesocyst, endocyst and metacyst). The semischematic illustration of the cross-section of resting cyst is shown in Fig. 1B.

Ectocyst. In a light microscope, the ectocyst was not distinguishable from the mesocyst (Fig. 2C). The ectocyst was a little more defined in TEM as an electron dense and compact layer (Fig. 3C). It was not structureless, 

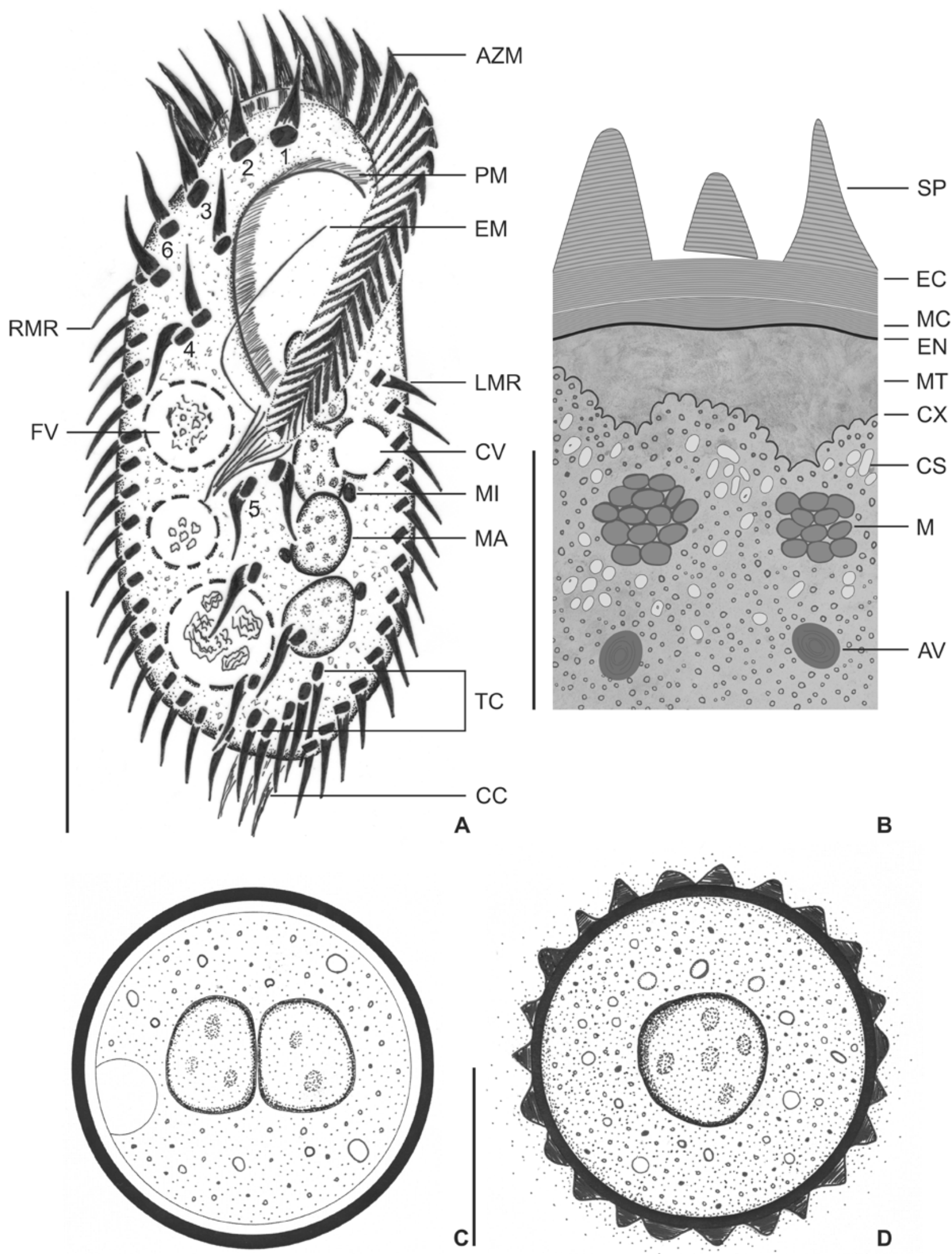
but built up from fine, horizontally arranged fibres/lamellae. The thickness of the ectocyst was quite variable, from $220 \mathrm{~nm}$ to $600 \mathrm{~nm}$ thick in TEM and was dependant on the age of the cyst. The ectocyst was its thickest at the stage of a mature cyst.

Spine-like protuberances (spines). The spine-like protuberances, which were also yellowish in vivo, were usually conical or pyramidal with a length of up to $3 \mu \mathrm{m}$ and base width of up to $2-3 \mu \mathrm{m}$. The size of the protuberances varried within in a single cysts. The distance between the individual protuberances was from $1 \mu \mathrm{m}$ to $2 \mu \mathrm{m}$. On one half of the cell surface, about 36-46 protuberances were recognised in vivo. About 20-28 protuberances were presented around the circumference of each resting cyst. The protuberances on the cyst surface lacked a surrounding membrane and composed of a mass of thin fibres (Figs 3C, E, F). The same composition as the ectocyst indicated, that the protuberances are generated only by the ectocyst fibres, which is well documented both in the light and electron microscopes. As the electron micrographs suggested, the ectocyst protuberances are not stable components of the cyst wall. During the excystation process, they did not stay attached to the cyst wall and separated very easily.

Mesocyst. The mesocyst, about 375-500 nm thick, was very similar to ectocyst, it was composed of very fine fibres, stacked next to each other. Sometimes we had a problem distinguishing these two layers (Fig. 3C). The boundaries were unclear.

Endocyst. In the light and electron microscopes, the endocyst appeared as a compact, narrow, dark and structureless part of the cyst wall. The endocyst was about $90-100 \mathrm{~nm}$ thick and was the thinnest layer of the wall. It was the main border between fibrillar part of the cyst wall (ecto- and mesocyst) and the metacyst (Fig. 3C).

Metacyst. The metacyst touched the ciliate cortex (Figs 3A, C, G, H). The thickness varied in range from $500 \mathrm{~nm}$ to $1300 \mathrm{~nm}$ in the TEM, especially in the thickest parts about $2 \mu \mathrm{m}$. The fine structure of metacyst was totally different from the other cell layers. It was very finely granular, but sometimes appeared like alveolar part of the cyst wall. On the other hand, in the light microscope, the metacyst was only a structureless space surrounding the regularly wrinkled cell cortex.

Cortex. The basal bodies were decomposed. Due to the fact that the preserved basal bodies were not visible at all in the TEM, resting cysts of $R$. quadrinucleata are of the kinetosome-resorbing type, which is typical for oxytrichids. In comparison to the cortex of interphase specimens, the cortex of encysted cells was not smooth. On the other hand, the cortex of encysted cells was strangely enough regularly waved and had many convex ridges. This structure of the cortex was recognisable only in the TEM (Figs 3G, H).

Cytoplasm. The cyst cytoplasm was densely granulated in TEM with many bright inclusions and granules. High-density granules were observed in the entire content of the cyst cytoplasm and were variable in size of about $100-300 \mathrm{~nm}$ in TEM. The typical shape was oval or globular. In the entire content of the cytoplasm were conspicuous structures, variable in shape and size. These "curious structures" (Fig. 3H), had a tendency to accumulate in the cell periphery, just below the surface of the cell. These structures were presented in each stages of resting cysts. Mitochondria (Figs 3A, B), arranged in distinct groups underneath the cell cortex were not very visible. Were globular or oval and measured 400 $700 \mathrm{~nm}$. We suppose that contrast agents had the problem of getting inside the cyst volume through a relatively impermeable and resistant cyst wall. We recognised the fused macronucleus only in the light microscope, located in the centre of the encysted cell and it was globular in shape. The fused macronucleus was very visible when the cyst wall cracked and the cell contents began to squeeze out (Figs 2E, F) . Micronuclei were not visible. Moreover, several autophagic vacuoles (Fig. 3D) were presented in the cytoplasm and contained wrinkled membraneous structures. The vacuoles size was approximately $900-1300 \mathrm{~nm}$ across in TEM.

Figs 1A-D. Rigidohymena quadrinucleata, trophic specimen and schematic illustrations of morphology of resting cysts. A - ventral view of a representative trophic specimen from the studied Slovak population; $\mathbf{B}$ - illustration of resting cyst based on transmission electron microscopy investigations; C, D - illustrations of young and mature resting cysts based on light microscopy investigations. 1-6 - six fronto-ventral-transverse cirral rows, AV - autophagic vacuole, AZM - adoral zone of membranelles, CC - caudal cirri, CS - "curious structures", CV - contractile vacuole, CX - cortex, EC - ectocyst, EM - endoral membrane, EN - endocyst, FV - food vacuole, LMR - left marginal cirral row, $\mathrm{M}$ - mitochondria, $\mathrm{MA}$ - macronucleus, $\mathrm{MC}$ - mesocyst, $\mathrm{MI}$ - micronucleus, MT - metacyst, $\mathrm{PM}$ - paroral membrane, $\mathrm{RMR}$ - right marginal cirral rows, $\mathrm{SP}$ - spine-like protuberances, $\mathrm{TC}$ - transverse cirri. Scale bars: $25 \mu \mathrm{m}(\mathrm{A}) ; 5 \mu \mathrm{m}(\mathrm{B}) ; 25 \mu \mathrm{m}(\mathrm{C}, \mathrm{D})$. 


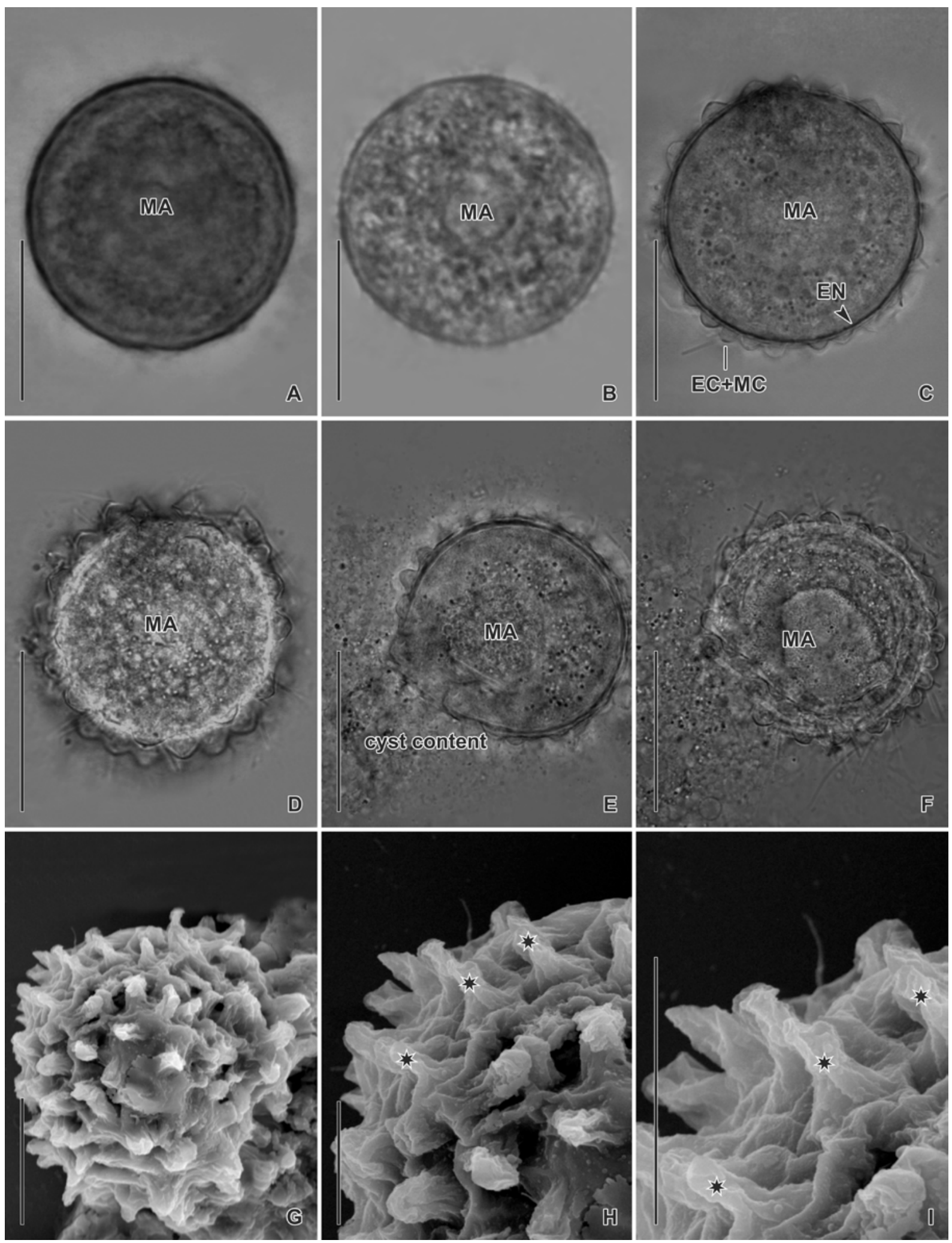

Figs 2A-I. Rigidohymena quadrinucleata, resting cysts in the light microscope and in the SEM. A, B - young resting cysts without surface ornamentation; $\mathbf{C}, \mathbf{D}$ - mature resting cysts with fully developed cyst wall (arrowhead marks endocyst); $\mathbf{E}, \mathbf{F}-$ the cyst contents is squeezed out, macronuclear mass is visible; $\mathbf{G}$ - full view of cyst; $\mathbf{H}, \mathbf{I}$ - surface view of the cyst wall showing the spine-like protuberances (asterisks). EC - ectocyst, EN - endocyst, MA - macronucleus, MC - mesocyst. Scale bars: $30 \mu \mathrm{m}(\mathrm{A}-\mathrm{F}) ; 20 \mu \mathrm{m}(\mathrm{G}) ; 10 \mu \mathrm{m}(\mathrm{H}, \mathrm{I})$. 

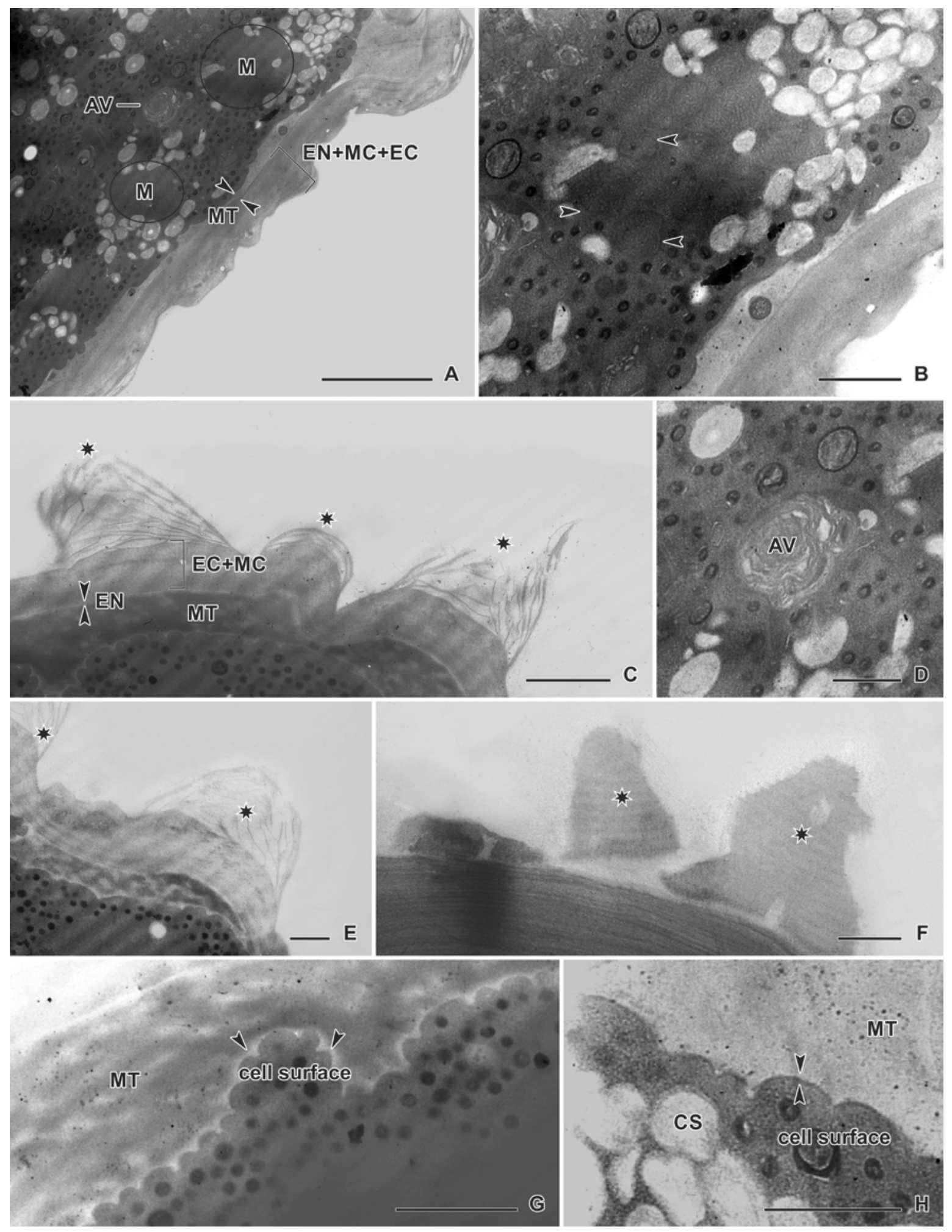

Figs 3A-H. Rigidohymena quadrinucleata, resting cysts in the TEM. A-C - cross sections showing the cyst wall, the spine-like protuberances and the content of the resting cyst (arrowheads mark the poorly visible group of mitochondria, asterisks mark the surface protuberances); D - detail of the autophagic vacuoles; $\mathbf{E}, \mathbf{F}$ - detail of the spine-like protuberances in the young and in mature resting cyst (asterisks mark the protuberances); $\mathbf{G}, \mathbf{H}$ - the cortex of encysted cells with many regularly waved convex ridges. AV - autophagic vacuole, $\mathrm{CS}$ - "curious structure”, EC - ectocyst, EN - endocyst, M - mitochondria, MC - mesocyst, MT - metacyst. Scale bars: $1 \mu \mathrm{m}(\mathrm{B}, \mathrm{C}, \mathrm{E}, \mathrm{F})$; $1,5 \mu \mathrm{m}(\mathrm{G}, \mathrm{H}) ; 2 \mu \mathrm{m}(\mathrm{A}, \mathrm{D})$. 


\section{Excystation}

Excystation of $R$. quadrinucleata was induced by hydrating the dry cultures (there was no difference in the excystation with respect to the culture type - in the watch glasses or Petri dishes). The process of excystation was observed only in vivo using light microscopy.

The first sign of the beginning of the excystation process was the appearence of the transparent space between the cyst wall and excysting cell. This space was on average about $2-3 \mu \mathrm{m}$. About 1 hour after the onset of excystation, the contractile vacuole appeared on the side of the cell. The pulsation of contractile vacuole began a few minutes after its discovery. The pulsation was relatively slow in approximately 15-20 seconds intervals. However, the pulsation of the contractile vacuole stopped approximately $20 \mathrm{~min}$ after it began to pulsate. The second important sign of the early stage of excystation $(1-1.5 \mathrm{~h})$ were the first active movements of the excysting cell. The quick, asynchronous movement was highly visible in the cysts whose cytoplasm became more transparent due to the passive diffusion of water from the enviroment into the cell. The most conspicuous feature of excystation was definitely the formation of excystation vacuole. The excystation vacuole in the first moments of its existence was not a regular sphere. The movement of regenerating cells became faster and more pronounced. The excystation vacuole did not pulsate, but increased in size and gradually expanded. The regenerating specimens still rotated. When the vacuole occupied about one-half (or only one-third) of the total volume of the cell cytoplasm, the cyst wall was ruptured by the pressure of the excystation vacuole. The outer layer of the cyst wall was ruptured in several places. The emergence pore was not present. The cell left the resting cyst around 2-3 h. Based on our examination of the excystation process of $R$. quadrinucleata, we identified two different modes of excystation - standard and rare mode. During the standard mode (Figs 4A-I), a regenerating specimen escaped within the single, thin, transparent membrane (Figs 4C-I). As soon as the cell left the resting cyst, the excystation vacuole quickly shrank and disappeared completely. The contractile vacuole reappeared and the pulsation was faster, in approximately 5-7 seconds intervals. The regeneration of excysted specimen continued within the surrounding membrane in the outer enviroment. After 10-15 min it ruptured and resorbed by enviroment. The full-motile specimen swam out. The movement of regenerated cells was a little slower during the first 2-3 min after leav- ing the membrane. A short time after leaving the resting cyst the posterior part of the cell was a little crumpled. In the following few minutes, the cell took a typical ovate to a long elliptical body shape. The difference in size was about $20-30 \%$ between the average size of the newly-excysted and interphase specimens. The structure of ectocyst remained also in the empty cysts, the spine-like protuberances were still quite recognisable.

During the second type of excystation (Figs 5A-I), the so called rare mode, the regenerating specimen broke the transparent membrane first (Figs 5C-E), instead of breaking the whole cyst wall. The membrane remained inside the cyst. Then the rest of the cyst wall was ruptured by the moving cell and the pressure of the excystation vacuole and the cell left the resting cyst. The transparent membrane remained in the empty resting cyst as a residual body. This mode was relatively rare, we recorded it only in about $10-20 \%$ of resting cysts. The basic schemes of main stages of the standard and rare excystation modes are shown in Fig. 6.

\section{DISCUSSION}

\section{Ultrastructure of resting cysts and the origin of sur- face ornamentation}

The ultrastructure of resting cysts has been studied in several oxytrichids, e.g. in Walker et al. (1975), Calvo et al. (1983), Berger (1999), Gutiérrez et al. 2003, Foissner et al. (2007), Benčat'ová et al. (2016), Li et al. (2017) and others. The resting cysts of Rigidohymena quadrinucleata has typical oxytrichid characteristics. First, the cysts belong to the kinetosome-resorbing cysts - KR-type according to Walker and Maugel (1980) or Oxytricha-type according to Matsusaka et al. (1989). A fine structural study of the cyst wall of $R$. quadrinucleata revealed a few other similarities to the resting cysts of oxytrichids. For most oxytrichids, a fusion of macronuclear nodules to the one mass during the encystation process, formation of autophagic vacuoles and mitochondrial packing are typical (Calvo et al. 1986, Berger 1999, Gutiérrez et al. 2003). In addition to these similarities, we observed significant difference from the basic ultrastructural characteristics of resting cysts of other oxytrich ciliates. The cortex of encysted cell in the resting cyst was neither smooth nor irregular, but regularly waved and had many convex ridges. The irregular surface of encysted cell is characteristic, e.g. for Parentocirrus hortualis by Benčat'ová et al. (2016), 


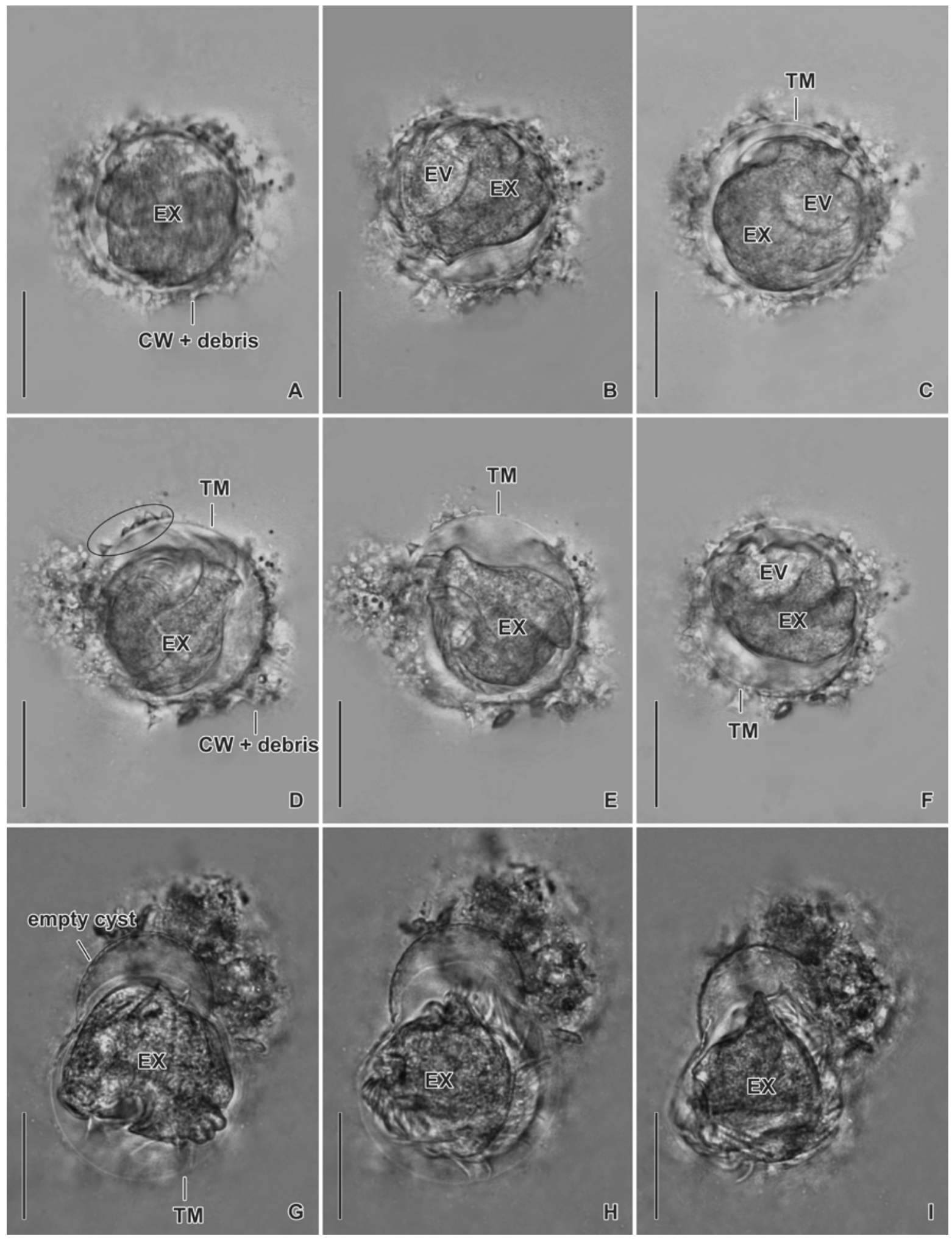

Figs 4A-I. Rigidohymena quadrinucleata, resting cysts and excystants in the light microscope, the standard mode of excystation. A-F - the beginning of excystation with formation of excystation vacuole and the cyst wall ruptures under the pressure of excystant and excystation vacuole (circular area marks the individual protuberances that were separated from the cyst wall); G-I - during the standard mode, the excystant breaks the cyst wall within the thin, transparent membrane. CW - cyst wall, EV - excystation vacuole, EX - excystant, $\mathrm{TM}$ - transparent membrane. Scale bars: $30 \mu \mathrm{m}$. 


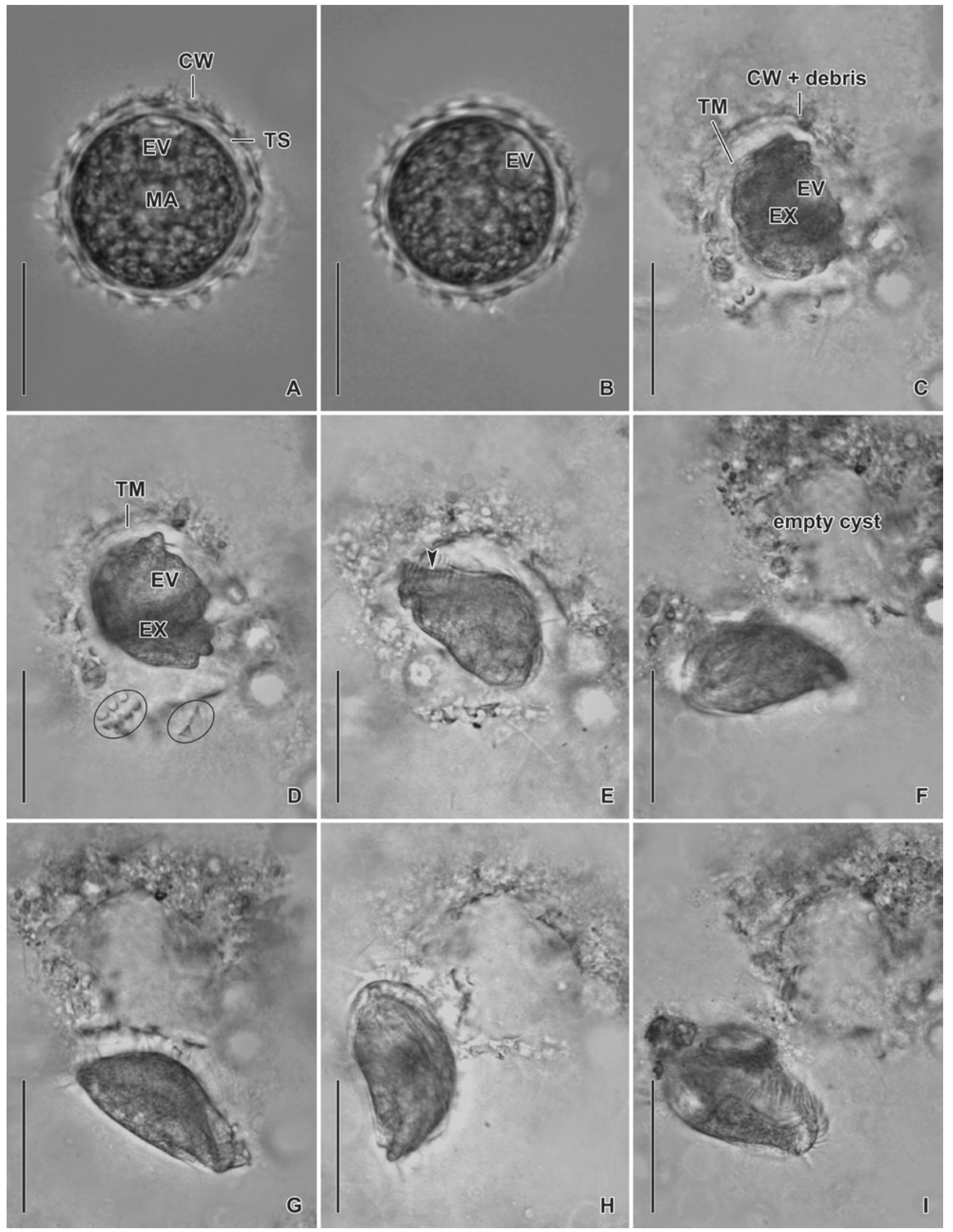


Oxytricha sp. by Berger (1999), Australocirrus cf. australis by Li et al. (2017), Histriculus similis [now accepted as Sterkiella quadrinucleatus (Sick, 1933) Berger, 1999] by Calvo et al. (1983), Calvo et al. (1986) and others. In comparison with different taxonomic group of ciliates, e.g. Colpodea, the cell cortex in the resting cyst of species Colpoda cucullus, localized beneath the cyst wall, is very similar to the vegetative cell membrane (Martin-González et al. 1992).

Among ciliates, the number of morphologically different cyst layers ranged between one and four. Oxytrichid ciliates show the highest number of cyst layers (Calvo et al. 1983, Delgado et al. 1987, Gutiérrez et al. 2003). The cyst wall of $R$. quadrinucleata is composed

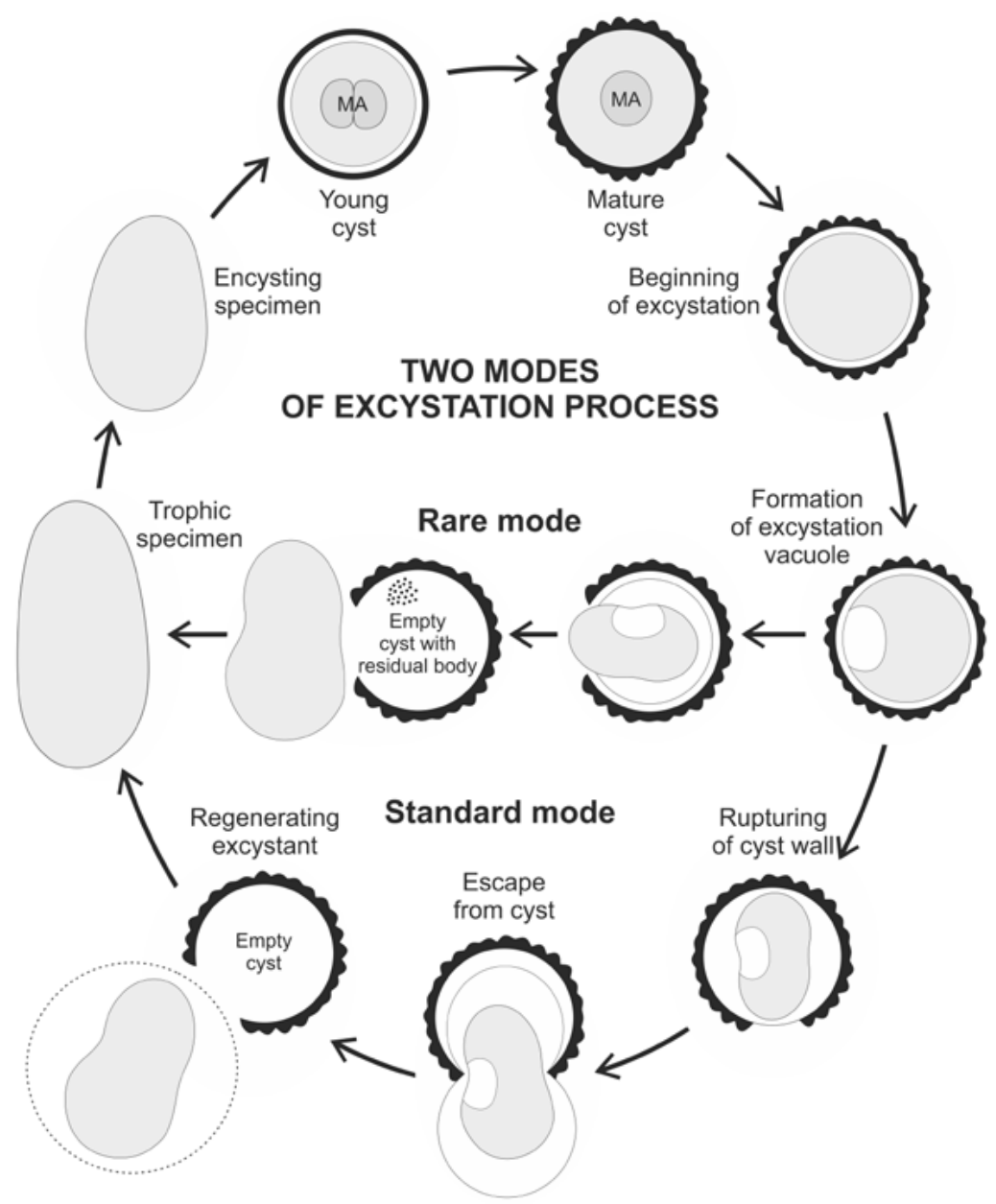

Fig. 6. Rigidohymena quadrinucleata, the basic scheme of two excystation modes. The standard mode: The beginning of excystation process is connected with formation of a transparent space between cyst wall and excysting cell. A little later, appears the excystation vacuole. The regenerating specimen breaks the cyst wall and escapes within the single, transparent membrane. The transparent membrane is broken by the excystant and resorbed in the enviroment. The rare mode: The beginning of excystation is associated, similarly, as in the standard mode, with formation of a transparent space and excystation vacuole. The regenerating specimen breaks the transparent membrane first, instead of breaking the whole cyst wall. Finally, the rest of the cyst wall is ruptured by the moving cell and the pressure of the excystation vacuole. The cell leaves the resting cyst. The transparent membrane remains in the empty cyst as a residual body.

\section{4}

Figs 5A-I. Rigidohymena quadrinucleata, resting cysts and excystants in the light microscope, the rare mode of excystation. A-E - the beginning of excystation with formation of excystation vacuole and the cyst wall ruptures under the pressure of excystant and excystation vacuole (circular area marks the individual protuberances that were separated from the cyst wall, arrowhead marks regenerating ciliature); F-I - during the rare excystation mode, the regenerating excystant breaks the transparent membrane first, inside the resting cyst. CW - cyst wall, EV - excystation vacuole, EX - excystant, MA - macronucleus, TM - transparent membrane, TS - transparent space. Scale bars: $30 \mu \mathrm{m}$. 
Tab. 1. The basic characteristics of resting cysts of Rigidohymena quadrinucleata compared to resting cysts of various ciliate species.

\begin{tabular}{|c|c|c|c|c|c|}
\hline Ciliate & $\begin{array}{l}\text { Taxonomic } \\
\text { classification } \\
\text { of the species }\end{array}$ & $\begin{array}{l}\text { Number of the } \\
\text { cyst layers }\end{array}$ & Cyst surface & Cyst wall color & References \\
\hline Bryophryoides ocellatus & Colpodea & $2\left(\mathrm{EC}^{\mathrm{a}}, \mathrm{EN}^{\mathrm{b}}\right)$ & smooth with irregular $\mathrm{ML}^{\mathrm{c}}$ & - & Bourland et al. (2014) \\
\hline Colpoda minima & Colpodea & $2(\mathrm{EC}, \mathrm{EN})$ & smooth & colourless & Foissner (1993) \\
\hline Colpoda steinii & Colpodea & $2(\mathrm{EC}, \mathrm{EN})$ & smooth with thin ML & colourless & Foissner (1993) \\
\hline Colpoda cucullus & Colpodea & $2(\mathrm{EC}, \mathrm{EN})$ & smooth with lepidosomes & colourless & $\begin{array}{l}\text { Foissner (1993); Funatani } \\
\text { et al. }(2010) \text {, Funadani et } \\
\text { al. }(2016)\end{array}$ \\
\hline Colpoda inflata & Colpodea & $2(\mathrm{EC}, \mathrm{EN})$ & smooth with thick ML & yellowish & Foissner (1993) \\
\hline Bursaria truncatella & Colpodea & $2(\mathrm{EC}, \mathrm{EN})$ & faceted with ridges* & - & Foissner (1993) \\
\hline Blepharisma undulans & Heterotrichea & $3\left(\mathrm{EC}, \mathrm{MC}^{\mathrm{d}}, \mathrm{EN}\right)$ & irregular flattened & red & $\begin{array}{l}\text { Mulish and Hausmann } \\
\text { (1989) }\end{array}$ \\
\hline Euplotes muscicola & $\begin{array}{l}\text { Spirotrichea } \\
\left(\text { Euplotidae) }^{\mathrm{e}}\right.\end{array}$ & $2(\mathrm{EC}, \mathrm{EN})$ & crests & - & Gu and Xu (1995) \\
\hline Phacodinium metchnikoffi & Phacodiniidae & $4\left(\mathrm{EC}, \mathrm{MC}, \mathrm{EN}, \mathrm{MT}^{\mathrm{f}}\right)$ & spines & - & Barrero (2010) \\
\hline Oxytricha granulifera & Oxytrichidae & $4(\mathrm{EC}, \mathrm{MC}, \mathrm{EN}, \mathrm{MT})$ & smooth with ML and granules & yellow-brown & Berger (1999) \\
\hline Laurentiella strenua & Oxytrichidae & $4(\mathrm{EC}, \mathrm{MC}, \mathrm{EN}, \mathrm{MT})$ & thorns & - & Foissner et al. (2007) \\
\hline Australocirrus cf. australis & Oxytrichidae & $4(\mathrm{EC}, \mathrm{MC}, \mathrm{EN}, \mathrm{MT})$ & slightly wrinkled & - & Li et al. (2017) \\
\hline Paraparentocirrus sibillinensis & Oxytrichidae & - & reticulate with ridges & - & Kumar et al. (2014) \\
\hline Rigidohymena quadrinucleata & Oxytrichidae & $4(\mathrm{EC}, \mathrm{MC}, \mathrm{EN}, \mathrm{MT})$ & spines & yellowish & Present study \\
\hline Parentocirrus hortualis & Oxytrichidae & $4(\mathrm{EC}, \mathrm{MC}, \mathrm{EN}, \mathrm{MT})$ & reticulate with ridges & colourless & Benčat’ová et al. (2016) \\
\hline
\end{tabular}

${ }^{\mathrm{a}} \mathrm{EC}$ - Ectocyst, ${ }^{\mathrm{b}} \mathrm{EN}$ - Endocyst, ${ }^{\mathrm{c}} \mathrm{ML}$ - Mucous layer, ${ }^{\mathrm{d}} \mathrm{MC}-$ mesocyst, ${ }^{\mathrm{f}} \mathrm{MT}$ - Metacyst = granular layer

${ }^{\mathrm{e}}$ Taxonomic classification of the species to the class and family

*Description of surface cyst of B. truncatella by Beers (1948) and Foissner (1993). The surface is very similiar to reticulate pattern of $P$. hortualis by

Benčat'ová et al. (2016) and P. sibillinensis by Kumar et al. (2014)

of four distinct layers, namely the innermost metacyst (= granular layer), the thin endocyst, the fibrous mesocyst and the compact outermost ectocyst. On the other hand, the resting cysts of colpodid ciliates consists of two or three layers (Martin-González et al. 1992, Foissner 1993, Funatani et al. 2010, Funadani et al. 2016), and the only, according to McArdle et al. (1980), ciliate with only one cyst layer is Tetrahymena rostrata (more information on the morphology of resting cysts of ciliates and references to them are summarised in Table 1).

As several studies suggest that the origin and structure of cyst ornamentation not only in hypotrichid (especially in family Oxytrichidae), but also in oligotrichid, and euplotid spirotrichs have great diversity and variability. In a comparative study on the fine structure of resting cysts in some representative ciliates, Foissner et al. (2007), recorded three different, very likely non-homologous cyst surface ornamentations, viz., (i) spines (generated by the outer ectocyst lamellae), (ii) thorns (generated by the mesocyst), and (iii) lepidosomes (produced in the cytoplasm content). Based on transmission electron microscopy analysis, the surface ornamentation of $R$. quadrinucleata belongs to "spines" and are generated by ectocyst lamellae. The ectocyst origin of surface ornamentations are typical for Paraurostyla weissei by Delgado et al. (1987), Steinia sphagnicola by Foissner et al. (2007), Pleurotricha sp. by Matsusaka (1976) and Oxytricha bifaria [now accepted as Stylonychia bifaria (Stokes, 1887) Berger, 1999] by Verni et al. (1984).

According to new study by Li et al. (2017), the ectocyst morphology of oxytrichids exhibits two different types of cyst surface, that is a spine-like protuberances (e.g. Rigidohymena tetracirrata, Laurentiella acuminata, Steinia sphagnicola, Oxytricha bifaria and others) or a slightly wrinkled surface of resting cyst (Gastrostyla steinii, Australocirrus cf. australis and others). On the basis of our data to morphology of resting cysts of Rigidohymena quadrinucleata, we identified the first type of cyst surface - spine-like protuberances. The 
specific spine-like ornamentation on the cyst surface, along with a unusual yellow color, were the most typical features of the resting cysts of $R$. quadrinucleata. This characteristics helped to identify the cysts more easily. Especially, the color was the most interesting features of resting cysts.

\section{Different excystation types in ciliates}

On the basis of literature references (Beers 1945, 1948, 1966; Repak 1968; Foissner 1993; Verni and Rosati 2011; Vd'ačný and Foissner 2012; Funadani et al. 2013; Benčat'ová et al. 2016; Benčatová and Tirjaková 2017) we recognised two basic types of emergence of motile specimens during the excystation process: (i) escape throught a special escape apparatus - emergence pore/operculum with a removable "plug"; and (ii) escape throuth a rupture of a cyst wall by pressure of moving cell and excystation vacuole.

The escape apparatus is typical for species, e.g. Dileptus sp. by Vd'ačný and Foissner 2012, Phacodinium metchnikoff by Barrero 2010, Bursaria truncatella, Bursaria ovata by Beers 1948 and Foissner 1993, Blepharisma stoltei by Repak 1968, Strombidium conicum by Kim and Taniguchi 1995 and Strombidium oculatum by Montagnes et al. 2002.

The escape by pressure of excysting cell and excystation vacuole occurs in many species of ciliates, such as Meseres corlissi by Müller 2007, Parentocirrus hortualis by Benčat'ová et al. 2016, Didinium nasutum by Beers 1945, Histriculus cavicola by Nakamura and Matsusaka 1991, and Oxytricha fallax by Hashimoto 1963. Although, the excystation vacuole is responsible for the rupture of the cyst wall, its origin is still discussed. Beers (1966) suggested that the excystation vacuole may be derived from contractile vacuole that stopped pulsate, as has been investigated in ciliates such as Nassula ornata. Funadani et al. (2013) documented that the excystation and contractile vacuoles never coexist in species Colpoda cucullus. These results corresponds well with the study of the species Bresslauides terricola by Benčat'ová and Tirjaková (2017). Benčatová et al. (2016) observed the same results in excystation process of Parentocirrus hortualis. Even, our observations of excystation of $R$. quadrinucleata suggest that the excystation vacuole did not pulsate and existed only after disappearance of pulsating contractile vacuole. In all these cases, the excystation apparatus is not present.

The excysting specimen of $R$. quadrinucleata usually escapes from the resting cysts surrounded by an elastic, transparent membrane and finally the surround- ing membrane is broken. Most authors call this special membranuos structure "endocyst" (Beers 1966, Vdačný and Foissner 2012, Funadani et al. 2013 and others). However, Benčat'ová et al. (2016) suggested that this membrane is not very likely the endocyst, because the real endocyst is still visible and recognisable in oxytrichids cysts during the excystation. Additionally, metacyst is formed between the endocyst and the excysting cell and we did not notice any remains of metacyst in this space. These arguments support our assumption about the origin of transparent membrane during the excystation of $R$. quadrinucleata. It is necessary to bring more light into this issue. In conclusion, the thin membrane enveloping excysting cell needs to be studied more and identified by using transmission electron microscopy.

One of the most important life cycle feature of $R$. quadrinucleata was the occurrence of two different types of excystment process. We identified two characteristic types of excystation process - standard and rare mode. The studies indicate that there are several excystation modes in other oxytrichids, too. The same excystation model was also described in the species Parentocirrus hortualis by Benčat'ová et al. (2016). In other groups of ciliates this excystation phenomenon has not yet been recorded. The cause of different modes of excystation in one species is still unknown and further research is needed.

Acknowledgements. First, we are grateful to Dr. Michal Martinka, Ing. Mária Čaplovičová from the Faculty of Natural Sciences, doc. RNDr. Miroslav Záhoran, CSc. from the Faculty of Mathematics, Physics and Informatics in Bratislava; Ing. Jana Nebesářová and our other very helpful colleagues from the Institute of Parasitology, Biology Centre in České Budejovice for their help with electron microscopy. We would also like to thank Mgr. Viktória Čabanová for collecting the moss samples. Financial support was provided by the Slovak Scientific Grant Agency (Project No. 1/0114/16).

\section{REFERENCES}

Barrero S. S. (2010) Caracterización filogenética de Phacodinium metchnikoffi: Análisis comparativo de datos morfológicos, morfogenéticos y moleculares. Universidad Comlutense de Madrid. $1-178$

Beers C. D. (1945) The excystation process in the ciliate Didinium nasutum. J. Elisha Mitchell Sci. Soc. 61: 264-275

Beers C. D. (1948) Excystation in the ciliate Bursaria truncatella. Biol. Bull. 94: 86-98

Beers C. D. (1966) The excystation process in the ciliate Nassula ornata Ehrbg. J. Protozool. 13: 79-83

Benčat'ová S., Tirjaková E. (2017) Prvonález druhu Bresslauides terricola (Foissner, 1987) Foissner, 1993 (Ciliophora, Colpodea) na Slovensku - cystické štádiá, en- a excystácia. Folia Faun. Slovaca 22: 31-40 
Benčat'ová S., Tirjaková E., Vd’ačný P. (2016) Resting cysts of Parentocirrus hortualis Voss, 1997 (Ciliophora, Hypotrichia), with preliminary notes on encystation and various types of excystation. Eur. J. Protistol. 43: 295-314

Berger H. (1999) Monograph of the Oxytrichidae (Ciliophora, Hypotrichia). Monogr. Biol. 78: 1-1080

Berger H. (2011) Monograph of the Gonostomatidae and Kahliellidae (Ciliophora, Hypotricha). Monogr. Biol. 90: 1-741

Berger H., Foissner W. (1997) Cladistic relantionships of oxytrichid hypotrichs (Protozoa, Ciliophora). Arch. Protistenk. 148: 125155

Bourland W. A., Wendell L., Hampikian G., Vd’ačný P. (2014). Morphology and phylogeny of Bryophryoides ocellatus n.g., n. sp. (Ciliophora, Colpodea) from in situ soil percolates of Idaho, U.S.A. Eur. J. Protistol. 50: 47-67

Calvo P., Torres A., Navas P., Perez-Silva J. (1983) Complex carbohydrates in the cyst wall of Histriculus similis. J. Gen. Microbiol. 129: 829-832

Calvo P., Torres A., Perez-Silva J. (1986) Ultrastructural and cytochemical study of the encystment in the hypotrichous ciliate Histriculus similis. Arch. Protistenkd. 132: 201-211

Delgado P., Calvo P., Torres A. (1987) Encystment in the hypotrichous ciliate Paraurostyla weissei: ultrastructure and cytochemistry. J. Protozool. 34: 104-110

Foissner W. (1984) Infraciliatur, Silberliniensystem und Biometrie einiger neuer und wenig bekannter terrestrischer, limnischer und mariner Ciliaten (Protozoa: Ciliophora) aus den Klassen Kinetofragminophora, Colpodea und Poluhymenophora. Stapfia 13: $1-165$

Foissner W. (1989) Morphologie und Infraciliatur einiger neuer und wenig bekannter terrestrischer und limnischer Ciliaten (Protozoa, Ciliophora). Sber. öst. Akad. Wiss. 196: 173-247

Foissner W. (1993) Colpodea (Ciliophora). Protozoenfauna 4: $1-798$

Foissner W. (1997) Soil ciliates (Protozoa: Ciliophora) from evergreen rain forests of Australia, South America and Costa Rica: diversity and description of new species. Biol. Fertil. Soils 25: 317-339

Foissner W. (2005) The unusual, lepidosome-coated resting cyst of Meseres corlissi (Ciliophora: Oligotrichea): transmission electron microscopy and phylogeny. Acta Protozool. 44: 217-230

Foissner W., Müller H., Agatha S. (2007) A comparative fine structural and phylogenetic analysis of resting cysts in oligotrich and hypotrich Spirotrichea (Ciliophora). Eur. J. Protistol. 43: 295-314

Foissner W. (2014) An update of basic light and scanning electron microscopic methods for taxonomic studies of ciliated protozoa. Int. J. Syst. Evol. Microbiol. 64: 271-292

Funadani R., Suetomo Y., Matsuoka T. (2013) Emergence of the terrestrial ciliate Colpoda cucullus from a resting cyst: rupture of the cyst wall by active expansion of an excystation vacuole. Microbes Environ. 28: 149-152

Funadani R., Sogame Y., Kojima K., Takeshita T., Yamamota K., Tsujizono T., Suizu F., Miyata S., Yagyu K.-I., Suzuki T., Arikawa M., Matsuoka T. (2016). Morphogenetic and molecular analyses of cyst wall components in the ciliated protozoan Colpoda cucullus Nag-1. FEMS Microbial. Lett. 363: fnw203

Funatani R., Kida A., Watoh T., Matsuoka T. (2010) Morphological events during resting cyst formation in the ciliate Colpoda cucullus. Protistology 6: 204-217

Gu F., Xu J. (1995) A TEM study on pre-excystment cellular structures of Euplotes encysticus. Cell Res. 5: 125-133
Gutiérrez J. C., Diáz S., Ortega R., Martín-González A. (2003) Ciliate resting cyst walls: A comparative review. Recent Res. Dev. Microbiol. 7: 361-379

Chen X., Yan Y., Hu X., Zhu M., Ma H., Warren A. (2013) Morphology and morphogenesis of a soil ciliate Rigidohymena candens (Kahl, 1932) Berger, 2011 (Ciliophora, Hypotricha, Oxytrichidae), with notes on its molecular phylogeny based on smallsubunit rDNA sequence data. Int. J. Syst. Evol. Microbiol. 63: 1912-1921

Hashimoto K. (1963) Formation of ciliatúre in excystation and induced re-encystment of Oxytricha fallax Stein. J. Protozool. 10: 156-166

Kim Y., Taniguchi A. (1995) Excystation of the oligothric ciliate Strombidium conicum. Aquat. Microb. Ecol. 9: 149-156

Kumar S., Foissner W. (2015) Biogeographic specializations of two large hypotrich ciliates: Australocirrus shii and A. australis and proposed synonymy of Australocirrus and Cyrtohymenides. Eur. J. Protistol. 51: 210-228

Kumar S., Bharti D., Marinsalti S., Insom E., La Terza A. (2014) Morphology, morphogenesis, and molecular phylogeny of Paraparentocirrus sibillinensis n. gen., n. sp., a "Stylonychinae Oxytrichidae" (Ciliophora, Hypotrichida) without transverse cirri. J. Eukaryot. Microbiol. 61: 247-259

Li Q., Sun Q., Fan X., Wu N., Ni B., Gu F. (2017) The differentiation of cellular structure during encystment in the soil hypotrichous ciliate Australocirrus cf. australis (Protista, Ciliophora). Animal Cells Syst. 21: 45-52

Martin-González A., Benítez A., Gutiérrez J. C. (1992) Ultrastructural analysis of resting cysts and encystment in Colpoda inflata. 2. Encystment process and a review of ciliate resting cyst classification. Cytobios 72: 93-106

Matsusaka T. (1976) An ultrastructural study of encystment in the hypotrichous ciliate Pleurotricha sp. Kumamoto. J. Sci. Biol. 13: $13-26$

Matsusaka T., Noguchi O., Yonezawa F. (1989) Cortical morphogenesis during encystment in a ciliate, Euplotes encysticus Yonezawa, 1985. Eur. J. Protistol. 24: 133-137

McArdle E. W., Bergquist B. L., Ehret Ch. F. (1980) Structural Changes in Tetrahymena rostrata during induced encystment. J. Eukaryot. Microbiol. 27: 388-397

Montagnes D. J. S., Lowe C. D., Poulton A., Jonsson P. (2002) Redescription of Strombidium oculatum Gruber 1884 (Ciliophora, Oligotrichia). J. Eukaryot. Microbiol. 49: 329-337

Mulish M., Hausmann K. (1989) Localization of chitin on ultrathin sections of cysts of two of the ciliated protozoa, Blepharisma undulans and Pseudomicrothorax dubius, using colloidal gold conjugated wheat germ egglutinin. Protoplasma 152: 77-86

Müller H. (2007) Live observation of excystation in the spirotrich ciliate Meseres corlissi. Eur. J. Protistol. 43: 95-100

Nakamura T., Matsusaka T. (1991) Effects of cyst age on excystation of the ciliate Histriculus cavicola (Kahl, 1935) (Ciliophora, Stichotrichia). Eur. J. Protistol. 37: 375-380

Repak A. J. (1968) Encystment and excystation of the heterotrichous ciliate Blepharisma stoltei Isquith. J. Protozool. 15: 407-412

Singh J., Kamra K. (2015) Morphology and molecular phylogeny of an Indian population of Cyrtohymena citrina (Ciliophora, Hypotricha), including remarks onontogenesis of Urosomoida-Notohymena-Cyrtohymena group. Eur. J. Protistol. 51: 280-289

Vd'ačný P., Foissner W. (2012) Monograph of the dileptids (Protista, Ciliophora, Rhynchostomatia). Denisia 31: 1-529

Verni F., Rosati G. (2011) Resting cysts: A survival strategy in Protozoa Ciliophora. Ital. J. Zool. 78: 134-145 
Verni F., Rosati G., Ricci N. (1984) The cyst of Oxytricha bifaria (Ciliata, Hypotrichida). II. The ultrastructure. Protistologica 20: $87-95$

Walker G. K., Maugel T. K. (1980) Encystment and excystment in hypotrich ciliates. II. Diophrys scutum and remarks on comparative features. Protistologica 16: 525-531

Walker G. K., Maugel T. K., Goode D. (1975) Some ultrastructural observations on encystment in Stylonychia mytilus (Ciliophora: Hypotrichida). Trans. Am. Microsc. Soc. 94: 147-154
Wang J., Li L., Warren A., Shao Ch. (2017) Morphogenesis and molecular phylogeny of the soil ciliate Rigidohymena quadrinucleata (Dragesco and Njine, 1971) Berger, 2011 (Ciliophora, Hypotrichia, Oxytrichidae). Eur. J. Protistol. 60: 1-12

Received on $25^{\text {th }}$ June, 2017; revised on $27^{\text {th }}$ August, 2017; accepted on $3^{\text {rd }}$ September, 2017 